\title{
LOCAL WISDOM-BASED CHARACTER EDUCATION IN TEACHING BALINESE TO ACHIEVE NATIONAL INTEGRATION OF A NATION
}

\author{
by \\ I Kadek Mustika \\ Universitas Pendidikan Ganesha \\ Jalan Udayana 11 Singaraj-Bali Telp. (0362) 22570 \\ ikadek_mustika@yahoo.com
}

\begin{abstract}
Indonesia, nowadays, still deals with complex problems, such as national disintegration and social disharmony of a nation. Many regions experience disunity which is started from smallest unit into larger unit. This problem will threaten the unity of Indonesia. It becomes a serious problem so that it is important to optimize the role of education which leads to the insertion of character education in early learning. Teacher is expected to be able to implement the character education, including the preparation, implementation, and evaluation. The implemented character education should be synergized to the local wisdom of each region because it has its own cultural values which could be guidances toward the attitude. Character education which is synergized with local wisdom aims at achieving the vision of integration and social harmony of a nation.
\end{abstract}

Keywords: local wisdom, character education, integration

\section{INTRODUCTION}

Indonesia has a philosophy which becomes the foundation to engage the Indonesian with all of its aspects named Pancasila. It also explains that Indonesian value is unity. The fourth paragraph of the opening of Indonesian basis regulation which was passed in 1945 (UUD 1945) also describes the value of peace and social judicature. The point of this concept is creating the integration and the social harmony of Indonesia. However, there are some conflicts which threaten the integration and become the reflection of disharmony in the society.

The issue of disintegration and social disharmony commonly happens together with the existence of the individualism in the human life. In Bali, the disunity also happens in a banjar or among pakraman. In the national level, some people on behalf of some certain organizations want to separate themselves from Indonesia. It is in line with Sumantri (in Budimansyah, 2011:1) who said that horizontal and vertical conflict which happen in social life is one of the effects of all crisis, which certainly lead to the national disintegration. Because of that, mental therapy is really needed as the effort to fix the divergence of physical attitude and national psychology and also improve the people's awareness to build our spirit as God's creatures, individual, and Indonesian.

Disintegration is a disunity condition; broken condition; loss of unity; disunion (Indonesian dictionary). What is meant by disunity is the threatened of Indonesia's unity which consists of thousand islands and 34 provinces in Indonesia. Whereas, social disharmony could be defined as an imbalance condition in life. Nowadays, the disintegration and social disharmony commonly happens in Indonesia, in the form of big into small scale. Until now, there are some regions which are threatened by national integration, such as Aceh, Papua, Poso and many other regions which might not identified yet. Especially in Bali, social disharmony phenomenon is easily found. For example, in family, big family, banjar, until pakraman village. The conflict among banjar or villages often happens. This kind of conflict has ever been happened on Saturday, $17^{\text {th }}$ of September 2011 between Kemoning village and 
Budaga village in Semarapura sub district of Klungkung regency. It happened because there was different perception of the existence of temple and ceremony in Pura Dalem which then cause serious conflict and loss of material and victims (Kumar, 2013).

This kind of disunity could threaten the national integration or national unity. The solution which has been arranged are fixing the physical damage and conducting national reconciliation among groups which have been quarreled or got discrimination (Sumantri in Budimansyah, 2011: 2). Education still becomes the key to solve this problem. Education should put the character education forward. Characters also cannot be separated from education, whether it is in formal education, non-formal education or informal education because the point of education is inserting meaningful values in human life through learning. Formal education at school also directs the students to build and improve the positive values. Like what has been stated by Dantes (2014: 69), many countries, including the advance country, believe that formal education is the significant process of nation and character building. Therefore, character education should be implemented in education.

\section{DISCUSSION}

Like what has been stated in the previous explanation that character education is very important to be implemented in education field. Talking about the problem in education must be related to learning. Because of that, a teacher must be able to conduct three phases of learning well, such as designing lesson plan, conducting learning process, and evaluating the learning process. A teacher is also expected to be able to integrate the character education into those three phases of learning process. The implementation of character education is integrated with learning. It is supported by Zubaedi (2011: 355) that the format of learning through character education with guidance is relevant as the effort to create the national character which is depreciating.

The first teacher's duty which is related with learning is designing lesson plan. Based on Permendikbud No. 65 Tahun 2013 which is about the standard of elementary and high school process, the lesson plan designed by the teacher should reflect the character education, which consists of (a) school identity, (b) lesson identity or theme/subtheme, (c) class/semester, (d) topic, (e) time allotment, (f) learning objectives, (g) basic competencies and indicator, (h) learning material, (i) teaching method, (j) learning media, (k) learning sources, (1) teaching scenario, (m) assessment.

According to those components of lesson plan, in implementing character education, ta teacher should modify or adapt the lesson plan that has been arranged. Daryanto and Darmiatun (2013: 189) stated that lesson plan should be able to guide the teacher in creating the learning process which could improve the character, so that lesson plan should be adapted. This adaptation covers (1) the improvement or modification on the components of learning objectives which refer to core competency and basic competency, (2) the improvement or modification on the components of learning activities, (3) on the components of the topic, and (4) on the components of assessment. These four components of lesson plan must show the character education, whether it is explicitly shown through learning objectives or it is implicitly shown through the arranged activities.

Besides those four components, the selection of teaching method also should be considered. According to Curriculum 2013, there are some teaching methods that can be implemented, such as Problem-Based Learning, Project-Based Learning, Cooperative Learning and many other methods. Those learning methods teach the students to work cooperatively in a small or even big group. Slavin (2005: 4-8) proposed various teaching methods in which the students could work in small group whose members come from different level of achievement, gender, and ethnic background to help each other in 
understanding the material. This method is effective to insert cooperativeness in order to avoid social disharmony and national disintegration.

Actually, learning process is the implementation of the plan that has been arranged in the form of lesson plan, but the teacher should conduct the learning process based on the plan. However, teacher could match the plan with the situation and condition. According to Sardiman (2014: 9), no wonder that the unpredicted phenomenon or interaction in the field could create new experience which becomes knowledge.

In implementing the character education into the learning process, the teacher applies the activities which have been arranged in the lesson plan, started from pre-activity, whilst activity and post-activity. If those activities have been done, it means that the teacher has implemented the character education in learning process implicitly. However, the teacher needs to explain verbally the character values which need to be implemented. It is in accordance with Mulyasa (2014: 105), who stated that there are five levels of thinking towards the attitude aspect, namely (1) receiving or attending, (2) responding, (3) valuing, (4) organizing, (5) characterizing. In other words, it is important for the students to receive, whether through the observation or listening to the verbal information about the values that have to be developed by the students.

Besides those activities in each phase, the teacher should understand the material well, implement appropriate teaching method and use media, learning tools and learning sources. In the learning process, there should be good communication between teacher and students. This is the part of cooperation to solve the learning obstacle. According to Lickona (2012: 140), the teacher-student relationship is the foundation of effective teaching. Thus, the success in implementing character education is really determined by the good communication between teacher and student.

In character education, there are some models or methods which could be implemented by the teacher, such as providing a model, giving verbal feedback, motivating, and also giving assignment. In learning, it is important for the teacher to provide good example in the form of good attitude to the students. Mulyasa (2013: 169) stated that teacher's model influences the students' individual development and improvement. This model has significant role and function in building the students' character in order to prepare and develop the human resources, and also bring welfare to society and country's development. In giving feedback, Klausmeier (in Sani, 2014: 31) said that receiving feedback is one of the teaching method in building character beside observing and receiving verbal information. Building the students' character using this method is conducted through giving feedback toward the behavior, such as by receiving or not receiving the behavior that is performed by the students.

After the teacher conducted learning process, the next duty is evaluating. Evaluating the learning result aims at recognizing whether the basic competency has been achieved (Kunandar, 2007: 356). The evaluation should include three aspects, such as cognitive, affective and psychomotor. Cognitive aspect is related to the thinking ability including understanding, recalling, applying, analyzing synthesizing and evaluating. Affective aspect is related to the attitude or character and psychomotor aspect is related to the physical movement and skill.

The evaluation which is conducted by the teacher should be used as the tools to improve the learning process. Arikunto (2005: 25) stated that the conducted evaluation should be based on the plan. It means that the evaluation has been arranged to identify the learning achievement. The information got through the evaluation can be used as the foundation to decide if the learning program, in this case it is related to values and attitudes, needs to be fixed. 
The evaluation plan that has been made by the teacher must be implemented to assess the cognitive, affective and psychomotor aspect and it should be based on the technique that has been chosen. For example, in assessing the affective aspect, the teacher can observe by noting the active students, filling self-assessment, and having assessment among students. For cognitive aspect, the teacher can hold spoken or written test. For psychomotor aspect, the teacher can conduct performance test.

The evaluation which is conducted by the teacher is for getting the formative, summative and confirmative score. The confirmative and formative evaluation are very important in improving the students' affective. When the teacher finds the students who perform bad attitude in the classroom, the teacher must admonish and ask them to build good attitude. Summative evaluation is conducted in order to have final evaluation whether the advices and confirmation that have been conducted by the teacher could change the students' attitude.

Character education which is implemented in teaching and learning process must be synergized with the culture or local wisdom. The values of the local wisdom become the basic fact of the education. It is also stated by Yunus (2014: 5) that the development of national character through local wisdom is really needed. The local wisdom should not only be used as a symbol but should also be used to solve the problems and support the improvement of a nation. The revitalization of the local wisdom in solving the problem is necessary to be conducted as an approach (Mustika, 2016). In teaching Balinese, the character education which is implemented should cover the local wisdom of Balinese, especially the values which are related to social awareness and spirit of nationalism in order to achieve the vision of national integration and social harmony of a nation.

The concept which has been believed by Balinese for long time is Tri Hita Karana. Tri Hita Karana is three sources of happiness which consist of parhyanagn (spiritual aspect), pawongan (social aspect), and palemahan (physical aspect) (Pujaastawa. 2014). The implementation of this concept is important to create the harmony of the relationship among people, especially the pawongan aspect. In Bali, for example, there are some terms, such as angawe sukaning won glen which teaches the people to make others happy; sagilik-saguluk sarpanaya paras-paros salunglung sabayantaka and asah, asih, asuh which reflect the togetherness among people in happiness and sadness. Besides those traditional terms, the concepts of harmonious relationship among people also could be seen in the religious concept. That concept is also known as menyama beraya which becomes the belief of Balinese society. All of the local wisdom is the social foundation which is very important to improve the solidarity of Balinese society.

In Balinese culture, which mostly contains Hindus belief, the pattern of the harmonious relationship among humans is stated in the concept of Tat Twam Asi which means "you are me and I am you". This concept contains the meaning of love and solidarity in having harmonious relationship among humans. Besides, there is also the concept of ahimsa (do not hurt others) which persuades the people to avoid violence. The Balinese local wisdom has reflected the values of character education and the teaching methods which are implemented in Curriculum 2013. It is based on Permendikbud No. 81 A. cooperative learning concerns on the value of respecting others, living together in a group, caring and keeping the unity. It is in line with the values of education.

The Synergy of Character Education, Local Wisdom, and Teaching Balinese in the Vision of National Integration and Social harmony of a Nation

Character Education
Balinese Local Wisdom
Teaching Balinese

(Curriculum 2013) 


\begin{tabular}{|c|c|c|}
\hline \multicolumn{3}{|c|}{ GENERAL PERSPECTIVE } \\
\hline $\begin{array}{l}\text { Government proposes } 18 \\
\text { character values, namely } \\
\text { religious, honest, } \\
\text { tolerant, discipline, hard } \\
\text { worker, creative, } \\
\text { independent, democratic, } \\
\text { curious, spirit of } \\
\text { nationalism, love nation, } \\
\text { respect the achievement, } \\
\text { communicative, love } \\
\text { peace, love reading, } \\
\text { environmentally care, } \\
\text { socially care, and } \\
\text { responsible. } \\
\text { (Kemendiknas Balitbang } \\
\text { Puskur, 2010) }\end{array}$ & $\begin{array}{l}\text { Bali has many local } \\
\text { wisdom which are taken } \\
\text { from Balinese life } \\
\text { perspective, whether it is } \\
\text { religion or culture, such } \\
\text { as Tri Hita Karana, Tat } \\
\text { Twam Asi, Karmapala, } \\
\text { Ahimsa, etc. }\end{array}$ & $\begin{array}{l}\text { Teaching Balinese by } \\
\text { implementing Curriculum } 2013 \\
\text { which based on Permendikbud No. } \\
81 \mathrm{~A} \text { through scientific approach } \\
\text { (observing, questioning, collecting } \\
\text { information, associating, } \\
\text { communicating). In relation with } \\
\text { the attitude, there is religious } \\
\text { attitude (in core competency no 1) } \\
\text { and social attitude 9in core } \\
\text { competency no } 2 \text { ). }\end{array}$ \\
\hline \multicolumn{3}{|c|}{ SYNERGY } \\
\hline $\begin{array}{l}\text { Based on those } 18 \\
\text { character values, the } \\
\text { characters which are } \\
\text { related with the vision of } \\
\text { integration and harmony } \\
\text { are tolerant, democratic, } \\
\text { spirit of nationalism, love } \\
\text { nation, communicative, } \\
\text { love peace and socially } \\
\text { care. }\end{array}$ & $\begin{array}{l}\text { Based on the local } \\
\text { wisdom, the vision of } \\
\text { integration and harmony } \\
\text { is closely related to the } \\
\text { concept of Tri Hita } \\
\text { Karana, especially the } \\
\text { pawongan. } \\
\text { Understanding the terms } \\
\text { manyama braya, asah } \\
\text { asih asuh, sagilik } \\
\text { saguluk salunglung } \\
\text { sabayantaka, paras- } \\
\text { paros sarpanaya. } \\
\text { Moreover, the other } \\
\text { concepts are Tat Twam } \\
\text { Asi, Ahimsa and } \\
\text { Karmapala. }\end{array}$ & $\begin{array}{l}\text { 1) In planning, the teacher design } \\
\text { lesson plan with character } \\
\text { education by inserting the } \\
\text { character values and local } \\
\text { wisdom in the learning } \\
\text { objectives, material, teaching } \\
\text { scenario and learning evaluation. } \\
\text { It is also used the cooperative } \\
\text { learning to perform the character } \\
\text { values and local wisdom. } \\
\text { 2) In implementing, teacher } \\
\text { conducts learning activities which } \\
\text { are humanistic based on the plan } \\
\text { that has been designed. Teacher } \\
\text { builds the close relationship and } \\
\text { harmony with the students. } \\
\text { 3) In evaluating, teacher evaluates } \\
\text { based on the character values } \\
\text { which have been planned and } \\
\text { conducted through the evaluation } \\
\text { principals. }\end{array}$ \\
\hline
\end{tabular}

In achieving the vision of the national integration and social harmony of a nation, there are various challenges in internal and external sector. Internal challenges come from the individual itself, such as redundant egoistic and individualistic. In this context, Balinese propose some terms in the society, such as "mati iba hidup kai" which means let other people die but I'm still alive. Through this life principal, Balinese are busy to manage their life but they do not care with others, so that the principal of menyama beraya is reducing. The external challenges come from external parties which want to trigger disunity or disharmony. In this era, Bali becomes the tourism area that could be the target to be disunited.

In educational context, especially learning Balinese, there are some challenges in achieving the vision which could be started from teacher professionalism context. Based on 
the government regulation No. 14 in 2015 about teacher and lecturer professionalism, the teacher should have academic qualification in which diploma or bachelor as the minimum degree and the department should be accredited. Besides, the teachers must have competencies which are related to their duty as teacher. The teachers should optimize the four competencies, such as pedagogical, professional, personal and social.

Based on the regulation made by the Minister of Country's Apparatus Development and Bureaucracy's Reformation No.16/2009 about teacher's functional position and the credit number, the improvement of teacher's profession could be conducted by self-development, such as attending functional training, workshop, seminar and conducting classroom action research.

Not only internal challenges, the external challenges such as the minimum facilities in conducting teaching and learning process also influences learning process. Furthermore, the implementation of Curriculum 2013 asks the students to use various media to support the learning process.

\section{CONCLUSION}

Indonesia, nowadays, faces some problems in national disintegration and social harmony of a nation. These two phenomena threaten the unity of Indonesia which has been built. It could be seen from the national scale into the smallest unit, like banjar. It is also happened in Bali in which these problems are seriously considered and need to optimize the character education. In solving the problem of national disintegration and social disharmony of a nation, the way that could be conducted is by deepening the character values, especially in formal environment, such as school. Teacher plays an important role in planning, implementing and evaluating. Teacher must be able to implement the character education in those three phases of learning by concerning on the regulation and learning theory. The character education which is implemented in learning should be in accordance with the local wisdom. Based on 18 character values, the characters which are related to the vision of integration and harmony are tolerant, democratic, spirit of nationalism, love nation, communicative, love peace, and socially care. These values are in line with asah-asih asuh, sagilik saguluk salunglung sabayantaka, paras paros sarpanaya which are included as the Balinese local wisdom. In learning, teacher should implement the values in planning, implementing, and evaluating phases besides the other values, such as social and religious.

In achieving the vision of national integration and social harmony of a nation, there are some internal and external challenges. It is also happened in the implementation at school. The challenges which come from the teacher are the teachers' qualification and competencies. The external challenge is the school facilities which also plays important role in learning process.

The authors would like thank to lecturers at Universitas Pendidikan Ganesha especially I Nengah Suandi for thought supported of this study.

\section{REFERENCES}

Arikunto, S. (2005). Dasar-dasar evaluasi pendidikan. Jakarta: PT Bumi Aksara

Budimansyah, Dasim and Kokom K. (2011). Pendidikan karakter: Nilai inti bagi upaya pembinaan kepribadian bangsa. Bandung: Widya Aksara Press

Dantes, N. (2014). Landasan pendidikan: Tinjauan dari dimensi makropedagogis. Singaraja: Undiksha

Daryanto and Suryati D. (2013). Implementasi pendidikan karakter di sekolah. Yogyakarta: Gava Media 
Kumar, S. (2013). Peran kepemimpinan majelis madya Desa Pakraman Klungkung dalam resolusi konflik sosial masyarakat (Studi kasus bentrok antara warga Kemoning dengan warga Budaga Semarapura Klungkung Bali. lib.ui.ac.id/file?file=pdf/abstrak20350669.pdf. Downloaded on $28^{\text {th }}$ of August, 2016

Kunandar. (2007). Guru profesional: Implementasi kurikulum tingkat satuan pendidik (KTSP) dan sukses dalam sertifikasi guru (Revision Edition). Jakarta: PT Raja Grafindo Persada

Lickona, T. (2012). Character matters (Persoalan karakter): Bagaimana membantu anak mengembangkan penilaian yang baik, integritas, dan kebajikan penting lainnya. Jakarta: PT Bumi Aksara

Mulyasa, E. (2014). Pengembangan dan implementasi Kurikulum 2013.Bandung: PT Remaja Rosdakarya

Mustika, I K. (2016). Kearifan lokal, jati diri bangsa. Daily opinion on Bali Post on Tuesday, $12^{\text {th }}$ of July, 2016

Permendikbud RI Nomor 65 Tahun 2013 which is about the standard of elementary and high school process. http://akhmadsudrajat.files.wordpress.com/2013/06/03-a-salinanpermendikbud-no-65-th-2013-ttg-standar-proses.pdf. Downloaded on $28^{\text {th }}$ of August, 2016

Pujaastawa, IBG. (2014). Kebudayaan Bali. Presented on Workshop for Police in Klapa Bali Pecatu Resort on $22^{\text {nd }}$ of August, 2014

Sani, R A. (2014). Pembelajaran saintifik untuk implementasi Kurikulum 2013. Jakarta: PT Bumi Aksara

Sanjaya, W. (2008). Perencanaan dan desain sistem pembelajaran. Jakarta; Kencana Prenada Media Group

Sardiman. (2014). Interaksi dan motivasi belajar mengajar. Jakarta: PT RajaGrafindo Persada Slavin, R. E. (2005). Cooperative Learning: Theory, research and practice (Translated by N. Yusron). London: Allymand Bacon.

Suyanto and Djihad, A. (2013). Bagaimana menjadi calon guru dan guru profesional. Yogyakarta: Multi Pressindo.

Yunus, R. (2014). Nilai-nilai kearifan lokal (local genius) sebagai penguat karakter bangsa: Studi empiris tentang Huyula. Yogyakarta: Deepublish

Zubaedi. (2011). Desain pendidikan karakter. Jakarta: Kencana Penada Media Group 